\title{
The effect of substituting wheat bran with cumin seed meal on laying performance, egg quality characteristics and fatty acid profile in laying hens
}

\author{
Ahmed A. Saleh ${ }^{*}$, Ashia Zaki ${ }^{1}$, Ahmed El- Awady ${ }^{1}$, Khairy Amber ${ }^{1}$, Neamat Badwi', \\ Yahya Eid ${ }^{1}$, and Tarek A. Ebeid ${ }^{1,2}$ \\ ${ }^{1}$ Department of Poultry Production, Faculty of Agriculture, Kafrelsheikh University, Kafrelsheikh, Egypt \\ ${ }^{2}$ Department of Animal Production and Breeding, College of Agriculture and Veterinary Medicine, \\ Qassim University, Buraydah, Saudi Arabia
}

\begin{abstract}
SALEH, A. A., A. ZAKI, A. EL- AWADY, K. AMBER, N. BADWI, Y. EID, T. A. EBEID: The effect of substituting wheat bran with cumin seed meal on laying performance, egg quality characteristics and fatty acid profile in laying hens. Vet. arhiv 90, 47-56, 2020.
\end{abstract}

\section{ABSTRACT}

The objective of the present study was to investigate the effect of substituting wheat bran (WB) with cumin seed meal (CSM) on laying performance, egg quality characteristics and egg-yolk fatty acids profile in laying hens. A total of 180 Bovans hens at 55 weeks of age were divided randomly into three treatments. The CSM was incorporated into a standard corn- and soybean meal-based diet by replacing 0, 50, and 100\% of WB [i.e., 100\% WB (control), 50\% $\mathrm{WB}+50 \% \mathrm{CSM}$ and $100 \% \mathrm{CSM}$ ] from 55 to 61 weeks of age. Body weight was measured at the beginning and end of the experiment. Feed intake, hen-day egg production and egg weight were recorded daily. At 61 weeks of age, 30 eggs were taken at random from each treatment group to determine the egg quality characteristics. Replacing $100 \%$ of WB by CSM did not affect body weight, however, hen-day egg production, egg weight and egg mass significantly increased, while feed conversion ratio significantly decreased $(\mathrm{P}<0.05)$. Haugh unit, shell thickness and yolk color significantly increased by CSM substitution in comparison with 100\% WB. Plasma concentrations of total cholesterol, triglycerides, LDL-cholesterol and glutamic oxalacetic transaminase (GOT) significantly decreased by replacing WB with CSM, while, plasma HDL-cholesterol significantly increased. Furthermore, the liver malondialdehyde (MDA) concentration significantly decreased, while vitamin E, linoleic acid and alpha-linolenic acid significantly increased $(\mathrm{P}<0.05)$ due to CSM inclusion. Therefore, it could be concluded that substitution of WB with CSM could improve laying performance and egg quality characteristics, and reduce lipid peroxidation in laying hens.

Key words: cumin seed meal; wheat bran; layers; egg quality; lipid peroxidation; fatty acids

\section{Introduction}

A recent increase in the price of energy sources, such as yellow corn and plant oils, has led to the addition of fibers to poultry feed as a method to decrease feed costs. Thus, it is important to understand the effects of these alternative dietary feed ingredients on the birds' production performance, and allow for proper formulation of current poultry diets. It is well known that high fiber feed ingredients might result in negative effects on digestion and absorption of nutrients in broiler chickens (PAIK, 2003). However, inclusion of high fiber ingredients in high levels to layer diets

\footnotetext{
*Corresponding author:

Dr. Ahmed Ali Saleh, Department of Poultry Production, Faculty of Agriculture, Kafrelsheikh University, Kafrelsheikh 333516, Egypt, E-mail: ahmed.saleh1@agr.kfs.edu.eg
} 
does not have any negative effect on performance in broilers (WALUGEMBE et al., 2015).

There have been several experiments involving the use of dietary fiber ingredients, such as wheat bran (WB), rice bran, sunflower seed meal and cumin seed meal (CSM), in both broilers and growing laying hens' diets, however, there are few reports concerning the use of fiber ingredients in laying hens during the production period (YAO et al., 2007; ANDERSSON et al., 2014). Moreover, these days poultry rations are formulated with ingredients rich in energy and/ or protein, which are usually high in bulk density. In order to increase bulkiness and improve the balance between the energy and protein contents of such rations, WB is normally used at levels up to $40-50$ $\mathrm{g} / \mathrm{kg} \operatorname{diet}$ (WILLATGAMUWA et al., 1998). WB is composed of about 53\% dietary fiber (xylans, lignin, cellulose, and galactan, fructans) and bioactive compounds, such as alkylresorcinols, ferulic acid, flavonoids, carotenoids, lignans and sterols (APPRICH et al., 2013; ANDERSSON et al., 2014; DE BRIER et al., 2014). Also, WB contains a rich stock of lignans and proteins, with balanced amino acid content, bioactive compounds, phytic acid, antioxidants, vitamins and minerals (JAVED et al., 2012). Nowadays in Egypt, CSM has been found to be a locally cheaper feed ingredient than WB. However, Egypt is one of the leading cumin seed (Cuminum cyminum) exporters in the world. Cumin seeds contain $20-40 \mathrm{mg} / \mathrm{g}$ of volatile oils (LUCCHESI et al., 2004), mainly a mixture of cymol or cymene and cuminic aldehyde, or cyminol, which is its chief constituent (PRADEEP et al., 1993). Cumin seeds contain $62 \mathrm{~g}$ moisture, 177-230 g protein, $238 \mathrm{~g}$ fat, $91 \mathrm{~g}$ fiber, $355 \mathrm{~g}$ carbohydrates and $77 \mathrm{~g}$ mineral matter $\mathrm{kg}^{-1}$. Out of the 18 amino acids identified, eight were indispensable, and the first limiting amino acid was tryptophan (BADR and GEORGIEV, 1990). Although there are a vast number of reports on the nutritive value and medicinal effects of cumin seeds and the extracted oil in humans and animals (CHINTHU et al., 1997; JOE and LOKESH, 1997; GAGANDEEP et al., 2003), there is no documented work on the use of CSM as an ingredient in poultry rations (MANSOORI et al., 2006).

Cumin seeds have also been widely used in traditional medicine for several benefits, e.g. as digestive, appetite and immune stimulants, (GILANI et al., 2004) antibacterial agents and antioxidants (BOURGOU et al., 2012). The major pharmacologically active constituents of essential oils in cumin seed are: thymoquinone, dithymoquinone, thymohydroquinone and thymol (GHOSHEH et al., 1999), while selenium, DL- $\alpha$-tocopherol, DL$\gamma$ - tocopherol, and all-trans-retinol are among the important antioxidants present in cumin seed oil (ALSALEH et al., 2006). Thus, it could be hypothesized that the substitution of WB with CSM might enhance the laying performance and fatty acid profile in eggyolk. To our knowledge, a few researchers have conducted experiments investigating the effects of CSM inclusion on laying performance, egg quality characteristics and egg-yolk fatty acid profile in laying hens. Therefore, the aim of the present study was to evaluate the nutritional effects of CSM as a substitute for WB in commercial laying hen rations, on laying performance, egg quality characteristics and egg-yolk fatty acid profile in laying hens.

\section{Materials and methods}

A total of 180 Bovans hens at 55 weeks of age with $70.5 \%$ egg production were individually housed in laying cages in an open-sided building under a $16 \mathrm{~h}$ light: $8 \mathrm{~h}$ dark lighting schedule in the research farm of the Faculty of Agriculture, Kafrelsheikh University, Egypt. The hens were randomly divided into three experimental treatments. Each treatment group (60 hens) was further randomly divided into 4 replicates of 15 hens.

The birds were fed, ad libitum, diets containing 40 $\mathrm{kg} /$ ton of WB (control), and WB was replaced by $50 \%$ and $100 \%$ CSM for the second and third treatments from 55 to 61 weeks of age. The experimental diets were $100 \%$ WB (control), 50\% WB+50\% CSM, and $100 \%$ CSM. The birds were fed a standard layer diet $(18 \%$ crude protein; $2750 \mathrm{kcal} \mathrm{ME,} \mathrm{4 \%}$ $\mathrm{Ca}$ per $\mathrm{kg}$ diet, Table 1). Diets were calculated to meet the recommendations of the National Research Council for brown Bovans laying hens. The chemical composition of CSM was $16 \%$ crude protein; $2900 \mathrm{kcal}$ ME per $\mathrm{kg}$ diet, $0.43 \%$ calcium, $0.30 \%$ phosphorous, $2.19 \%$ total fat, $20.9 \%$ fiber, $0.5 \%$ lysine, and 0.21 methionine. Feed intake was measured weekly, whereas hen-day egg production and egg weight were recorded daily throughout the 
experimental period. The feed conversion ratio (FCR, $\mathrm{kg}$ of feed/kg of eggs) for the entire experimental period was calculated on a cage basis from egg production, egg weight, and feed intake.

Table 1. Composition of the experimental diets

\begin{tabular}{|l|c|c|c|}
\hline $\begin{array}{l}\text { Feed } \\
\text { ingredients }\end{array}$ & $\begin{array}{c}100 \% \\
\text { WB }\end{array}$ & $\begin{array}{c}50 \% \text { WB }+ \\
50 \% \text { CSM }\end{array}$ & $\begin{array}{c}100 \% \\
\text { CSM }\end{array}$ \\
\hline Yellow corn & 573 & 580 & 581 \\
\hline $\begin{array}{l}\text { Soybean meal, } \\
\text { 46\% }\end{array}$ & 183 & 185 & 195 \\
\hline $\begin{array}{l}\text { Corn gluten } \\
\text { meal, 62\% }\end{array}$ & 86 & 66 & 56 \\
\hline Limestone & 95 & 95 & 95 \\
\hline $\begin{array}{l}\text { Di-calcium } \\
\text { Phosphate }\end{array}$ & 18 & 18 & 18 \\
\hline NaCl & 2.5 & 2.5 & 2.5 \\
\hline DL- methionine & 1 & 1 & 1 \\
\hline L-lysine & 2 & 2 & 2 \\
\hline Soy oil & 10 & 4 & 2 \\
\hline Wheat bran & 40 & 20 & ---- \\
\hline Cumin seed meal & ---- & 20 & 40 \\
\hline Premix* & 3 & 3 & 3 \\
\hline $\begin{array}{l}\text { Sodium } \\
\text { bicarbonate }\end{array}$ & 1.5 & 1.5 & 1.5 \\
\hline $\begin{array}{l}\text { Potassium } \\
\text { carbonate }\end{array}$ & 3 & 3 & 3 \\
\hline Calculated analysis & \multicolumn{3}{|l}{} \\
\hline $\begin{array}{l}\text { ME } \\
\text { (Kcal/kg diet) }\end{array}$ & 2754 & 2756 & 2757 \\
\hline Crude protein, \% & 18.05 & 18.06 & 18.08 \\
\hline Calcium, \% & 4.08 & 4.07 & 4.08 \\
\hline Fiber, \% & 2.8 & 2.9 & 3.1 \\
\hline Phosphorus, \% & 0.43 & 0.43 & 0.43 \\
\hline Methionine, \% & 0.46 & 0.46 & 0.46 \\
\hline Lysine, \% & 0.95 & 0.96 & 0.97 \\
\hline $\begin{array}{l}\text { Feed Cost, } \\
\text { EGP/kg }\end{array}$ & 5.543 & 5.433 & 5.347 \\
\hline
\end{tabular}

*Premix content; Vitamin mineral premix (units per kilogram of feed): vitamin A, 10,000 IU; vitamin D3, 3,500 IU; vitamin E, $35 \mathrm{IU}$; menadione, $1.5 \mathrm{mg}$; riboflavin, $5 \mathrm{mg}$; pantothenic acid, $8 \mathrm{mg}$; vitamin $\mathrm{B} 12,0.012 \mathrm{mg}$; pyridoxine, $1.5 \mathrm{mg}$; thiamine, $1.5 \mathrm{mg}$; folic acid, $0.5 \mathrm{mg}$; niacin, $30 \mathrm{mg}$; biotin, 0.06 $\mathrm{mg}$; iodine, $0.8 \mathrm{mg}$; copper, $10 \mathrm{mg}$; iron, $80 \mathrm{mg}$; selenium, 0.3 $\mathrm{mg}$; manganese, $80 \mathrm{mg}$; zinc, $80 \mathrm{mg}$.
At 61 weeks of age, 30 eggs per treatment group were collected to measure egg quality traits and total cholesterol content in the egg-yolk. At the end of the experimental period, 15 birds from each treatment were randomly chosen, weighed, anaesthetized and slaughtered. Blood plasma and liver samples were taken and stored at $-20{ }^{\circ} \mathrm{C}$ for subsequent analysis.

Plasma total cholesterol, triglycerides, HDLcholesterol, LDL-cholesterol, glutamic oxalacetic transaminase (GOT), glutamate pyruvate transaminase (GPT), total protein, albumin and globulin concentrations were measured calorimetrically, using commercial kits (Diamond Diagnostics, Egypt) according to the procedure outlined by the manufacturer.

Lipid peroxidation in the liver was measured in the form of malondialdehyde (MDA), according to RICHARD et al. (1992). Analysis of fatty acids was carried out using a Shimadzu gas chromatograph GC-4 CM (PFE), equipped with flame ionization detector (FID). A standard mixture of methyl esters was analyzed under identical conditions prior to running the samples. The retention times of the unknown sample of methyl esters were compared with those of the standard. The concentration of methyl esters was calculated by the triangulation method, using the method described by RADWAN (2008) and SALEH (2013). Vitamin E concentration in egg-yolk was determined by HPLC, according to the method described by SURAI et al. (1995).

The differences between treatments were statistically analyzed by one-way ANOVA in a completely randomized design, using Statistical Packages for Social Sciences (2001). The significant differences between the means of treatment were compared by Duncan's new multiple-range test. P $<0.05$ was set as the limit of significance.

\section{Results}

The results showing the effects of replacing of WB by CSM on laying performance (body weight, hen-day egg production, feed intake, egg mass, FCR and egg weight) are presented in Table 2. The inclusion of CSM in the diet affected laying performance parameters. Body weight was not 
Table 2. The effect of substitution of wheat bran (WB) with cumin seed meal (CSM) on production performance in laying hens

\begin{tabular}{|l|c|c|c|c|}
\hline & $100 \% \mathrm{WB}$ & $50 \% \mathrm{CSM}$ & $100 \%$ CSM & P-value \\
\hline Initial body weight, g & $1566.67 \pm 63.94$ & $1573.33 \pm 45.83$ & $1570 \pm 62.00$ & 0.91 \\
\hline Final body weight, g/30d & $1613.33 \pm 65.38$ & $1611.11 \pm 47.71$ & $1610.56 \pm 59.91$ & 0.87 \\
\hline Hen-day egg production, \% & $70.44 \pm 0.67^{\mathrm{b}}$ & $72.56 \pm 0.988^{\mathrm{ab}}$ & $74.11 \pm 0.964^{\mathrm{a}}$ & 0.052 \\
\hline Egg weight, g & $59.11 \pm 0.877^{\mathrm{b}}$ & $60.16 \pm 0.46^{\mathrm{ab}}$ & $61.06 \pm 0.398^{\mathrm{a}}$ & 0.051 \\
\hline Feed intake, g/d & $117.9 \pm 2.64^{\mathrm{a}}$ & $111.2 \pm 1.55^{\mathrm{b}}$ & $110.3 \pm 1.11^{\mathrm{b}}$ & 0.034 \\
\hline Egg mass, g of egg/hen/d & $41.62 \pm 0.61^{\mathrm{b}}$ & $43.67 \pm 0.83^{\mathrm{a}}$ & $45.24 \pm 0.59^{\mathrm{a}}$ & 0.042 \\
\hline Feed conversion ratio, g feed/g egg & $2.83 \pm 0.4^{\mathrm{a}}$ & $2.55 \pm 0.3^{\mathrm{a}}$ & $2.43 \pm 0.4^{\mathrm{b}}$ & 0.033 \\
\hline
\end{tabular}

Values presented are the means and their standard error of 60 per treatment. ${ }^{\mathrm{a}, \mathrm{b}}$ Mean values followed by different letters in the same row are significantly different $(\mathrm{P}<0.05)$. WB - wheat bran; CSM - cumin seed meal.

Table 3. The effect of substitution of wheat bran (WB) with cumin seed meal (CSM) on egg quality in laying hens

\begin{tabular}{|l|c|c|c|c|}
\hline & $100 \% \mathrm{WB}$ & $50 \% \mathrm{CSM}$ & $100 \% \mathrm{CSM}$ & P-value \\
\hline Egg weight, g & $59.5 \pm 0.69$ & $59.3 \pm 1.35$ & $59.4 \pm 1.32$ & 0.41 \\
\hline Albumin height, mm & $5.36 \pm 0.53$ & $5.88 \pm 0.60$ & $6.20 \pm 0.37$ & 0.22 \\
\hline Yolk height, mm & $16.2 \pm 0.27$ & $16.12 \pm 0.25$ & $16.89 \pm 0.28$ & 0.12 \\
\hline Albumin width, cm & $2.56 \pm 0.25^{\mathrm{a}}$ & $2.08 \pm 0.25^{\mathrm{ab}}$ & $1.74 \pm 0.26^{\mathrm{b}}$ & 0.053 \\
\hline Yolk width, cm & $3.51 \pm 0.07$ & $3.57 \pm 0.11$ & $3.50 \pm 0.07$ & 0.11 \\
\hline Haugh unit & $112.8 \pm 1.84^{\mathrm{b}}$ & $120.4 \pm 2.11^{\mathrm{a}}$ & $122.9 \pm 2.11^{\mathrm{a}}$ & 0.065 \\
\hline Shell thickness, $\mu \mathrm{m}$ & $366.1 \pm 9.99^{\mathrm{b}}$ & $408.9 \pm 14.67^{\mathrm{a}}$ & $414.4 \pm 12.92^{\mathrm{a}}$ & 0.042 \\
\hline Yolk color & $7.06 \pm 0.18^{\mathrm{b}}$ & $7.93 \pm 0.30^{\mathrm{a}}$ & $8.11 \pm 0.27^{\mathrm{a}}$ & 0.026 \\
\hline
\end{tabular}

Values presented are the means and their standard error of 30 eggs per treatment. ${ }^{\mathrm{a}, \mathrm{b}}$ Mean values followed by different letters in the same row are significantly different $(\mathrm{P}<0.05)$. WB - wheat bran; CSM - cumin seed meal.

Table 4. The effect of substitution of wheat bran (WB) with cumin seed meal (CSM) on blood biochemical parameters in laying hens

\begin{tabular}{|l|c|c|c|c|}
\hline & $100 \% \mathrm{WB}$ & $50 \% \mathrm{CSM}$ & $100 \% \mathrm{CSM}$ & P-value \\
\hline Total protein, mg/dL & $5.2 \pm 0.15$ & $5.63 \pm 0.38$ & $5.5 \pm 0.31$ & 0.22 \\
\hline Albumin, mg/dL & $2.13 \pm 0.18$ & $2.37 \pm 0.088$ & $2.23 \pm 0.033$ & 0.16 \\
\hline Globulin, mg/dL & $3.1 \pm 0.058$ & $3.27 \pm 0.296$ & $3.13 \pm 0.120$ & 0.21 \\
\hline GOT, U/I & $263.3 \pm 13.33^{\mathrm{a}}$ & $226.7 \pm 16.67^{\mathrm{ab}}$ & $213.3 \pm 3.33^{\mathrm{b}}$ & 0.056 \\
\hline GPT, U/I & $6.167 \pm 4.41$ & $5.833 \pm 6.67$ & $5.5 \pm 5.0$ & 0.17 \\
\hline Total cholesterol, mg/dL & $210.7 \pm 5.81^{\mathrm{a}}$ & $200 \pm 10.58^{\mathrm{ab}}$ & $178.7 \pm 1.33^{\mathrm{b}}$ & 0.062 \\
\hline HDL-cholesterol, mg/dL & $31.33 \pm 0.33^{\mathrm{b}}$ & $34.67 \pm 1.20^{\mathrm{ab}}$ & $42.00 \pm 4.16^{\mathrm{a}}$ & 0.051 \\
\hline LDL-cholesterol, mg/dL & $171 \pm 4.9$ & $161.7 \pm 11.32^{\mathrm{a}}$ & $123 \pm 9.50^{\mathrm{b}}$ & 0.032 \\
\hline Triglycerides, $\mathrm{mg} / \mathrm{dL}$ & $22.93 \pm 1.220^{\mathrm{a}}$ & $20.9 \pm 1.0^{\mathrm{ab}}$ & $18.67 \pm 0.762^{\mathrm{b}}$ & 0.063 \\
\hline
\end{tabular}

Values presented are the means and their standard error of 15 samples per treatment. a,b Mean values followed by different letters in the same row are significantly different $(\mathrm{P}<0.05)$. GOT - Glutamic oxaloacetic transaminase; GPT - glutamic pyruvic transaminase, HDL - High density lipoprotein;LDL - Low density lipoprotein; WB - wheat bran; CSM - cumin seed meal. 
significantly affected by replacing WB with CSM, however, feed intake significantly decreased and hen-day egg production and egg weight increased $(\mathrm{P}<0.05)$. Also, FCR was improved by feeding $100 \%$ CSM.
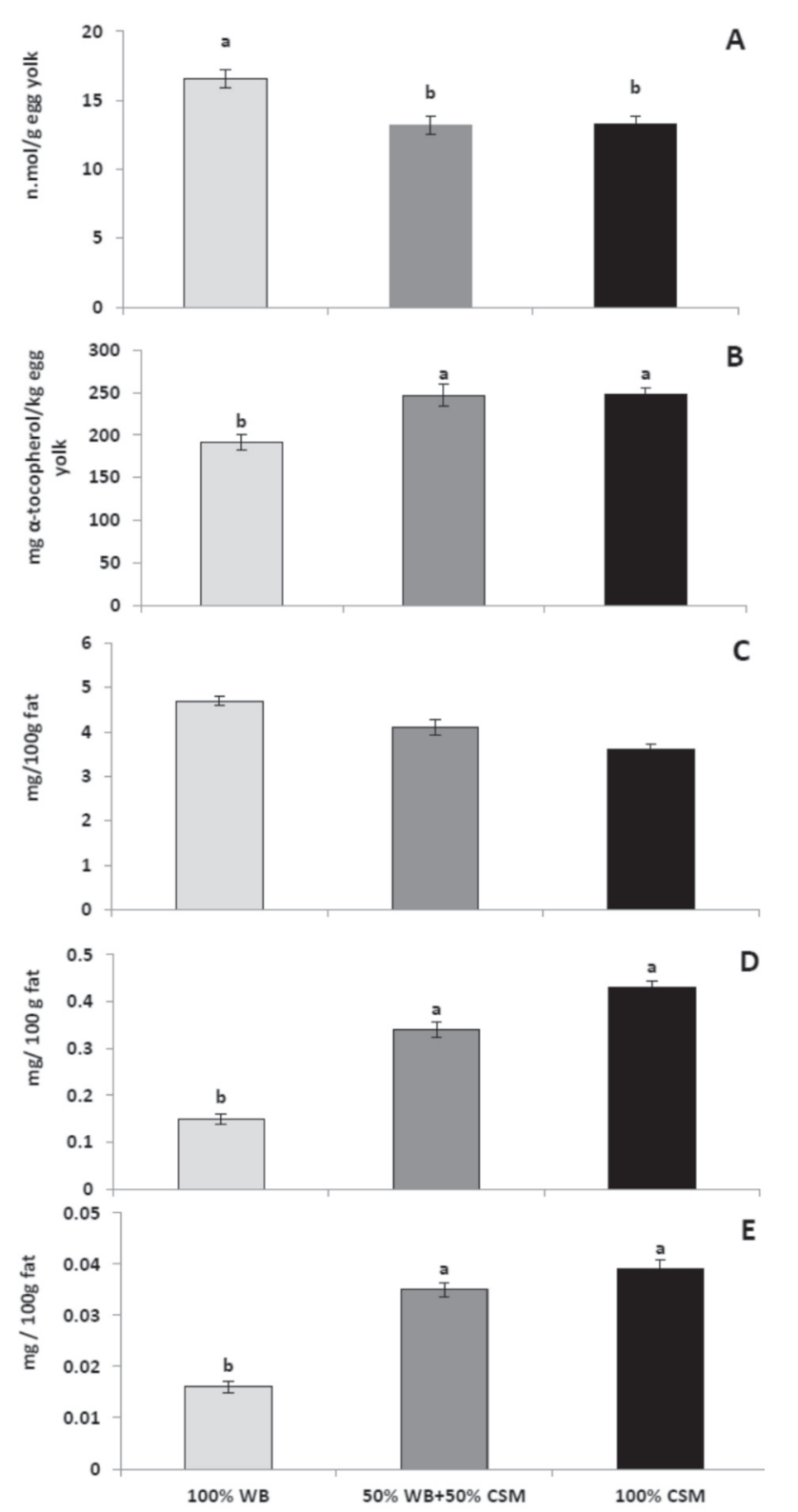

Fig. 1. The effect of substitutions of wheat bran (WB) with cumin seed meal (CSM) on liver MDA (A), Vitamin E (B), Palmitic acid (C), Linoleic acid (D) and Linolenic acid (E) in laying hens. Values are expressed as mean $\pm \mathrm{SE}$; mean values with different letters are significantly different from each other $(\mathrm{P}<0.05)$.
Data illustrating the effect of CSM inclusion on egg quality characteristics are presented in Table 3. Albumin and yolk heights and yolk width were not significantly affected by replacing WB with CSM, however, albumin width, Haugh unit, shell thickness and yolk color significantly increased with substitution of 50 or $100 \%$ WB with CSM $(\mathrm{P}<0.05)$.

The data presented in Table 4 show the effect of replacing of WB with CSM on the blood plasma constituents of the laying hens. Total protein, albumin, globulin and GPT concentrations were not significantly affected, however, plasma GOT, total cholesterol, LDL-cholesterol and triglycerides concentrations significantly decreased with substitution of $100 \%$ WB with CSM $(\mathrm{P}<0.05)$. Plasma concentration of HDL- cholesterol increased significantly through the dietary treatments $(\mathrm{P}<0.05)$.

Fig. 1 shows the effect of replacing WB with CSM on liver MDA content (as lipid peroxidation index), and egg-yolk concentrations of vitamin E, palmitic acid, linoleic acid and linolenic acid. Liver MDA content significantly decreased thorugh 50 or $100 \%$ substitution of WB with CSM, while vitamin $\mathrm{E}$, linoleic acid and linolenic acid concentrations significantly increased $(\mathrm{P}<0.05)$. Egg-yolk palmitic acid content was not significantly affected by dietary treatments.

\section{Discussion}

The major objective of the present study was to establish whether laying performance and egg quality characteristics might be affected by replacing WB with CSM in the diet of laying hens. In the present study, it was found that hen-day egg production, egg weight and FCR were significantly improved by substitution of $100 \%$ WB with CSM (Table 2). These results are in agreement with MANSOORI et al. (2006) who observed that the addition of 25 or $50 \mathrm{~kg} /$ ton of CSM instead of WB improved egg weight and FCR, while body weight and feed intake were not significantly influenced. The improvement in performance may be due to the nutritional value of CSM. Cumin seeds are nutritionally rich; they provide high amounts of fat (especially monounsaturated fat), protein, 
dietary fibers, vitamins B and E and several dietary minerals, especially iron (BETTAIEB et al., 2011). Also, the improvements in laying performance due to dietary inclusion of CSM might be attributed to the digestion-stimulating and antimicrobial properties of cumin (GALIB and AL-KASSI, 2010). Moreover, there is evidence that the active compounds of cumin enhance bile acid concentration and stimulate the secretion of digestive enzymes, including amylases, proteases, and lipases (SRINIVASAN, 2005). Moreover, PLATEL and SRINIVASAN, (2001) reported that feeding cumin shortened the food transit time by $25 \%$, which probably correlated with its positive influence on either digestive enzymes or bile secretion.

Haugh unit, shell thickness and yolk color significantly improved with CSM substitution in comparison with $100 \% \mathrm{WB}$, however, other egg quality characteristics were not significantly affected in the current study (Table 3). These results are in agreement with MANSOORI et al. (2006) who observed that the addition of $50 \mathrm{~kg} /$ ton of CSM instead of WB improved yolk and shell quality characteristics. It is possible that CSM inclusion increased the secretion of bile acids and enhanced lipase activity, leading to enhancement of the absorption of fat and fat-soluble compounds, including $\beta$-carotenoids, which finally resulted in improving the yolk color score (PLATEL and SRINIVASAN, 2000). Moreover, dietary CSM enhanced calcium and phosphors digestibility, which is the cause of improved shell thickness (PLATEL and SRINIVASAN, 2001). Therefore, it is possible that dietary CSM might be involved in increasing serum calcium concentrations, and hence increasing shell calcification which consequently leads to the improvement of shell quality features.

Serum biochemistry reference values might provide valuable information about physiological status, and provide an indication of health status and disease resistance in birds. Changes in internal milieu can be caused by various factors, one of which involves diet and feed (CAPCAROVÁ and KOLESÁROVÁ, 2010). Plasma lipids were significantly changed, whereas a significant decrease in total cholesterol, LDL-cholesterol and triglycerides was observed, while HDLcholesterol significantly increased. However, plasma total protein was not significantly affected by substitution of WB with CSM (Table 4). These results are in accord with ALY et al. (2003), who reported that broiler chicks fed black CSM had lower $(\mathrm{P} \geq 0.05)$ plasma cholesterol concentrations than those fed the control diet. The decrease in the plasma level of cholesterol is expected to be due to the active compound found in cumin, which acts as an inhibitor to active enzyme hepatic 3hydroxyl-3 methyglutaryl coenzyme A (HMGCoA) that synthesizes cholesterol (CROWELL, 1999; SALEH et al., 2015). Furthermore, this reduction in serum cholesterol could be contributed in some cases to a reduction in some hormones secreted by the cortex of the adrenal glands, which in turn causes a reduction in the secretion of fatty acids from the adipose tissues, or a reduction in fat oxidation, leading to a reduction in the level of fatty acids, including blood cholesterol (GANONG, 2005). The flavonoids presented in cumin seeds are recognized to have antioxidant activity and improve the antioxidant system. SAMANI and FARROKHI (2014) demonstrated that cumin extract significantly decreased the level of oxidized lowdensity lipoprotein. Similarly, SAMBAIAH and SRINIVASAN (1991) proved that dietary inclusion of cumin reduced serum and liver cholesterol concentrations in normal and hypercholesterolemia inducing diets in rats. The changes in the mean values of plasma HDL-cholesterol in the birds fed cumin seed may be due to the possible mechanism of the hypocholesterolaemic and hypolipidemic action of cumin seed oil, which suppresses the hepatic activities of lipogenic and cholesterogenic enzymes, such as: malic enzyme, fatty acid synthase, glucose-6-phosphatase dehydrogenase (CHI et al., 1982) and 3 hydroxyl 3 methyl-glutaryl-CoA (HMG-CoA) reductase (QURESHI et al., 1987).

As shown in Table 4, serum GOT $(\mathrm{P}<0.05)$ and GPT $(\mathrm{P}>0.05)$ concentrations decreased in those birds fed CSM (Table 4). These marker enzymes are normally localized within the cells of the liver, heart, gill, kidney, muscles and other organs (YAKUBU et al., 2005). Moreover, these adaptive enzymes are of importance for diagnosis of diseases 
(BEŇOVÁ et al., 2003). It was reported that cumin seed relieves the deleterious effects of ischemiareperfusion injury on the liver in rats, as indicated by the titers of marker enzymes, total antioxidant capacity, total oxidative status, and myeloperoxidase in the liver tissue (YILDIZ et al., 2008).

In the current study, CSM showed an antioxidative effect by decreasing MDA content in the liver, and increasing vitamin $\mathrm{E}$ content in egg-yolks (Fig. 1). Free radicals are highly reactive oxygen species with unpaired electrons in their outermost shell (HAMID et al., 2010). Increased production of free radicals in the body can cause oxidative stress that ultimately leads to oxidative damage to important biomolecules, leading to many chronic diseases (POULSON et al., 1998). To cope with these radicals, the living system has an antioxidant enzyme defense system, or the animal may take antioxidants through its diet, as vitamins and minerals. Previous studies showed that cumin oils exhibited high antioxidant activity due to the flavonoids, particularly apigenin and luteolin, in cumin seeds (LEUNG et al., 1980). GAGANDEEP et al. (2003) reported that supplementation of cumin seeds $(2.5$ and $5 \%$ of diet) in mouse feed tended to increase superoxide dismutase, and catalase, and reduced glutathione, however, the activities of glutathione peroxidase and glutathione reductase remained unaltered by both doses of cumin. Similarly, cuminaldehyde was demonstrated to scavenge the superoxide anion (KRISHNAKANTHA and LOKESH., 1993). Further, JUHAINMI and GHAFOOR (2013) confirmed that the supplementation of cumin seed extract has greater DPPH radical scavenging activities in comparison to un-supplemented animals, and the antioxidant activity of cumin seed extracts ranged from 8.25 to $11.24 \mathrm{mg} / \mathrm{mL}$. They stated that the antioxidative potential increased with the increase in the phenolic compound content of cumin. The results graphically presented in Fig. 1. illustrate that feeding CSM had no significant effect on palmitic acid concentration in the egg-yolk, while linoleic acid and linolenic acid, as unsaturated fatty acids, significantly increased in the egg-yolks. These results were explained by ABDEL-AAL and ATTIA (1993) who reported that cumin seed has high levels of unsaturated fatty acids, particularly linoleic acid.

\section{Conclusion}

On the basis of the data presented above, it may be concluded that substitution of WB with CSM could improve laying performance and egg quality characteristics, and reduce lipid peroxidation in laying hens.

\section{References}

ABDEL-AAL, E. S., R. S. ATTIA (1993): Characterization of black Figure 2: Effect of Nigella sativa treatments and production interval on serum total lipids $(\mathrm{mg} / \mathrm{dL})$ levels, cumin (Nigella sativa): Chemical composition and lipids. Alex. Sci. Exchange J.14, 467-481.

AL-SALEH, I. A., G. BILLEDO, I. I. EL-DOUSH (2006): Levels of selenium, DL- $\alpha$-tocopherol, DL- $\gamma$ - tocopherol, all-trans-retinol, thymoquinone and thymol indifferent brandsof Nigella sativa seeds. J. Food Composition Analysis 19, 167-175.

DOI: 10.1016/j.jfca.2005.04.011

ALY, M., S. M. SHALASH, M. I. AMER, M. A. ABDELMAGEED (2003): Effect of substituting soybean meal by Nigella sativa meal on growth performance, carcass characteristics, blood constituents and sensory evaluation for broiler chicks. Mansoura Univ. J. Agri. Sci. 28, 17591781.

ANDERSSON, A. A. M., L. DIMBERG, P. AMAN, D. LANDBERG (2014): Recent findings on certain bioactive components in whole grain wheat and rye. J. Cereal Sci. 59, 294-311.

DOI: $10.1016 /$ j.jcs.2014.01.003

APPRICH, S., O. TIRPANALAN, J. HELL (2013): Wheat bran-based biorefinery 2 : valorisation of products. LWTFood Sci. Technolol. 56, 222-231.

DOI: $10.1016 /$ j.lwt.2013.12.003

BADR, F. H., E. V. GEORGIEV (1990): Amino acid composition of cumin seed (Cuminum cyminum L.). Food Chemist. 38,273-278.

DOI: $10.1016 / 0308-8146(90) 90184-6$

BEŇOVÁ, K., M. TOROPILA, M. FALIS, P. DVOŘÁK (2003): Influence of lionising radiation on the activity of selected adaptive enzymes in chickens and rats. Acta Vet. Brno 72, 201-205.

DOI: $10.2754 / \mathrm{avb} 200372020201$

BETTAIEB, I., S. BOURGOU, J. SRITI, K. MSAADA, F. LIMAM, B. MARZOUK (2011): Essential oils and fatty acids composition of Tunisian and Indian cumin (Cuminum cyminum L.) seeds: a comparative study. J. Sci. Food Agri. 91, 2100-2107.

DOI: $10.1002 /$ jsfa.4513 
BOURGOU, S., A. PICHETTE, B. MARZOUK, J. LEGAULT (2012): Antioxidant, anti-inflammatory, anticancer and antibacterial activities of extracts from Nigella sativa (black cumin) plant parts. J. Food Biochemist. 36, 539-546. DOI: 10.1111/j.1745-4514.2011.00567.x

CAPCAROVÁ, M., A. KOLESÁROVÁ (2010): Beneficial substances affecting internal milieu of animals. Slovak University of Agriculture, Nitra, $73 \mathrm{p}$.

CHI, M. S., E. T. KOH, T. J. STEWART (1982): Effects of garlic on lipid metabolism in rats fed cholesterol or lard. J. Nutrit. 112, 241-248.

DOI: $10.1093 / \mathrm{jn} / 112.2 .241$

CHINTHU, T. U., B. K. NARAINSWAMI, S. REVI (1997): Ethnoveterinary medicine for dairy cows. Proc Int Conf on Ethnoveterinary Medicine: Alternatives for Livestock, Pune.

CROWELL, P. L. (1999): Prevention and therapy of cancer by dietary monoterpenes. J. Nutrit. 129, 775s-778s.

DOI: $10.1093 / \mathrm{jn} / 129.3 .775 \mathrm{~s}$

DE BRIER, N., S. V., GOMAND, I. J., JOYE, B., PAREYT, C. M., COURTIN, J. A. DELCOUR (2014): The impact of pearling as a treatment prior to wheat roller milling on the texture and structure of bran-rich breakfast flakes. LWTFood Sci. Technolo.62, 668-674.

DOI: 10.1016/j.lwt.2014.08.015

GALIB, A. M, I. AL-KASSI (2010): Effect of feeding cumin Cuminum cyminum on the performance and some blood traits of broiler chicks. Pakistan J. Nutr. 9, 72-75.

DOI: $10.3923 /$ pjn.2010.72.75

GAGANDEEP, S. D., E. M'ENDIZ, A. R. RAO, R. K. KALE (2003): Chemopreventive effects of Cuminum cyminum in chemically induced forestomach and uterine cervix tumors in murine model systems. Nutr. Cancer. 47,171-180.

DOI: $10.1207 / \mathrm{s} 15327914 \mathrm{nc} 4702 \_10$

GANONG, W. F. (2005): Review of Medical Physiology. $16^{\text {th }}$ ed., Alange Medical Book, pp. 336-338.

GHOSHEH, O. A., A. A. HOUDI, P. A. CROOKS (1999): High performance liquid chromatographic analysis of the pharmacologically active quinines and related compounds in the oil of the black seed (Nigella sativa). J. Pharm. Biomed. Anal 19, 757-762.

DOI: $10.1016 / \mathrm{s} 0731-7085(98) 00300-8$

GILANI, A. H., Q. JABEEN, M. A. U. KHAN (2004): A review of medicinal uses and pharmacological activities of Nigella sativa. Pakistan J. Bio. Sci. 7,441-451.

HAMID, A. A., O. O. AIYELAAGBE, L. A. USMAN, O. M. AMEEN, A. LAWAL (2010): Antioxidants: Its medicinal and pharmacological applications. Afr. J. Pure Appl. Chem. $4,142-151$.

JAVED, M. M., S., ZAHOOR, S. SHAFAAT (2012): Wheat bran as a brown gold: nutritious value and its biotechnological applications. Afr. J. Microbiol. Res. 6, 724-733.

DOI: $10.5897 /$ ajmrx 11.035
JOE, B., B. R. LOKESH (1997): Prophylactic and therapeutic effects of n-3 polyunsaturated fatty acids, capsaicin, and curcumin on adjuvant induced arthritis in rats. J. Nutr. Biochemist. 8, 397-407.

JOE, B., U. J. S. PRASADARAO, B. R. LOKESH (1997): Presence of an acidic glycoprotein in the serum of arthritic rats: modulation by capsaicin and curcumin. Mol. Cell Biochem. 169, 125-134.

JUHAIMI, A. L., K. GHAFOOR, (2013): Extraction optimization and in vitro antioxidant properties of phenolic compounds from Cumin Cuminum cyminum L. seed. Inter. Food Res. J. 20, 1669-1675.

KRISHNAKANTHA, T. P., B. R. LOKESH (1993): Scanvenging of superoxide anions by spice principles. Indian J. Biochem. Biophys 30, 133-134.

LEUNG, A. Y (1980): Encyclopedia of Common Natural Ingredients used in Foods, Drugs and Cosmetics, John Wiley, Hoboken NJ.

LUCCHESI, M. E., F. CHEMAT, J. SMADJA (2004): An original solvent free microwave extraction of essential oils from spices. Flavour and Fragrance J. 19, 134-138.

DOI: $10.1002 / f f j .1274$

MANSOORI, B., M. MODIRSANEI, M. KIAEI (2006): Cumin seed meal as an alternative to wheat bran in commercial laying hen diets. J. Sci. Food Agric. 86, 2134-2139.

DOI: $10.1002 /$ jsfa.2587

PAIK, I. K (2003): Application of phytase, microbial or plant origin, to reduce phosphorus excretion in poultry production. Asian-Australas J. Anim. Sci 1, 124-135.

DOI: 10.5713 /ajas.2003.124

PLATEL, K., K. SRINIVASAN (2000): Stimulatory influence of select spices on bile secretion in rats. Nutr. Res. 20, 1493-1503.

DOI: $10.1016 / \mathrm{s} 0271-5317(00) 80030-5$

PLATEL, K., K. SRINIVASAN (2001): Studies on the influence of dietary spices on food transit time in experimental rats. Nutr. Res. 21, 1493-1503.

DOI: $10.1016 / \mathrm{s} 0271-5317(01) 00331-1$

POULSON, H. E., H. PRIEME, S. LOFT (1998): Role of oxidative DNA damage in cancer initiation and promotion. Eur. J. Cancer Prev. 7, 9-16.

PRADEEP, U., K., GEERVANI, B. O. EGGUM (1993): Common Indian spices: nutrient composition, consumption and contribution to dietary value. Plant Foods Hum. Nutr 44, 137-148.

DOI: $10.1007 / \mathrm{bf} 01088378$

QURESHI, A. A., T. D. CRENSHAW, N. ABUIREMEILEH, D. M. PETERSON, C. E. ELSON (1987): Influence of minor plant constituents on porcine hepatic lipid metabolism: Impact on serum lipid. Atherosclerosis 64, 109-115.

DOI: $10.1016 / 0021-9150(87) 90235-8$ 
RADWAN, N. L., R. A., HASSAN, E. M., QOTA, H. M. FAYEK (1978): Effect of natural antioxidant on oxidative stability of eggs and productive and reproductive performance of laying hens. Int. J. Poult. Sci 7, 134-150.

DOI: $10.3923 /$ ijps.2008.134.150

RICHARD, M. J., B., PORTAL, J., MEO, C., COUDRAY, A., HADJIAN, A. FAVIER (1992): Malondialdehyde kit evaluated for determining plasma and lipoprotein fractions that react with thiobarbituric acid. Clin. Chem 38, 704-709. DOI: $10.1093 /$ clinchem $/ 38.5 .704$

SALEH, A. A (2013): Effects of fish oil on the production performances, polyunsaturated fatty acids and cholesterol levels of yolk in hens. Emir. J. Food Agric. 25, 605-612.

DOI: $10.9755 /$ ejfa.v25i8.14005

SALEH, A. A., K., HAYASHI, D. IJIRI, A. OHTSUKA (2015): Effect of feeding Aspergillus awamori and canola seed on the growth performance and muscle fatty acid profile in broiler chicken. Anim. Sci. J. 86, 305-311.

DOI: $10.1111 /$ asj.12281

SAMANI, K. G., E. FARROKHI (2014): Effects of cumin extract on oxldl, paraoxanase 1 activity, FBS, total cholesterol, triglycerides, HDL-C, LDL-C, apo A1, and apo B in in the patients with hypercholesterolemia. Int. J. Med. Sci 8, 39-43.

DOI: $10.12816 / 0006070$

SAMBAIAH, K., K. SRINIVASAN (1991): Effect of cumin, cinnamon, ginger, mustard and tamarind in induced hypercholesterolemic rats. Die Nahrung. 35, 47-51.

DOI: 10.1002/food.19910350112

SRINIVASAN K. (2005): Spices as influencers of body metabolism: an overview of three decades of research. Food Res. Int. 38, 77-86.

DOI: $10.1016 /$ j.foodres.2004.09.001
SURAI, P., I. IONOV, A., BUZHIN, N. BUZHINA (1995): Vitamin E and egg quality. Proceedings of the $6^{\text {th }}$ European Symposium on the quality of eggs and egg products (Cepero, R., Ed.), Zaragoza, Spain, pp. 387-394.

WALUGEMBE, M., K. J. STALDER, M. F. ROTHSCHILD, M. E. PERSIA (2015): Effect of High Fiber Ingredients on the Performance, Metabolizable Energy and Digestibility of Broiler and Layer Chicks,. Animal Industry Report, AS 661, ASL R3000.

DOI: 10.31274/ans_air-180814-1321.

WILLATGAMUWA, S. A., K. PLATEL, G. SARASWATHI, K. SRINIVASAN (1998): Antidiabetic influence of dietary cumin seeds in streptozotocin induced diabetic rats. Nut. Res 18,131-142.

DOI: $10.1016 / \mathrm{s} 0271-5317(97) 00207-8$

YAKUBU, M. T., O. J. ADEBAYO, E. C. EGWIN, V. B. OWOLEYE (2005): Increased liver alkaline phosphatise and aminotransferase activities following administration of ethanolic extract of Khaya senegalensis stem bark to rats. Biochemist. 17, 27-32.

DOI: 10.4314/biokem.v17i1.32585

YAO, J. H., J. C. HAN, S. Y. WU, M. XU, L. L. ZHONG, Y. R. LIU, Y. J. WANG (2007): Supplemental wheat bran and microbial phytase could replace inorganic phosphorus in laying hen diets. Czech J. Anim. Sci. 52, 407-413.

DOI: $10.17221 / 2321$-cjas

YILDIZ, F (2008): Nigella sativa relieves the deleterious effects of ischemia reperfusion injury on liver. World J. Gastroenterol. 14, 5204-5209.

Received: 3 October 2018

Accepted: 29 December 2018

SALEH, A. A., A. ZAKI, A. EL-AWADY, K. AMBER, N. BADWI, Y. EID, T. A. EBEID: Učinak zamjene obroka od pšeničnih mekinja obrokom sa sjemenkama kima na nesenje, kvalitetu jaja i masnokiselinski profil u kokoši nesilica. Vet. arhiv 90, 47-56, 2020.

\section{SAŽETAK}

Cilj ovoga rada bio je istražiti učinak zamjene obroka s pšeničnim mekinjama (WB) obrokom sa sjemenkama kima (CSM) na nesenje, kvalitetu jaja te profil masnih kiselina u žumanjku jajeta kokoši nesilica. Ukupno je 180 Bovans kokoši u dobi od 55 tjedana slučajnim odabirom podijeljeno u tri pokusne skupine, u kojima su sjemenke kima dodane u standardni obrok s kukuruzom i sojom zamjenjujući 0, 50 i $100 \%$ pšeničnih mekinja. Tako je kontrolna skupina hranjena obrocima sa 100 \% pšeničnih mekinja, druga skupina s $50 \%$ obroka s pšeničnim mekinjama i 50 \% obroka sa sjemenkama kima, a treća skupina obrokom koji je sadržavao $100 \%$ sjemenki kima. Pokusno razdoblje je trajalo od 55. do 61. tjedna starosti nesilica. Tjelesna je masa mjerena na početku i na kraju pokusa. Unos hrane, dnevna 
proizvodnja jaja i njihova masa bilježili su se svaki dan. U dobi od 61 tjedna iz svake je skupine slučajnim odabirom uzeto 30 jaja kako bi se odredila njihova kvaliteta. Zamjenjujući $100 \%$ obrok od pšeničnih mekinja sjemenke kima nisu utjecale na tjelesnu masu, no ipak su dnevna proizvodnja, težina i masa jaja znakovito porasle, dok se stopa konverzije hrane znakovito smanjila $(\mathrm{P}<0,05)$. Haugh-ova jedinica, debljina ljuske i boja žumanjka znakovito su porasle u skupinama u kojima su pšenične mekinje zamijenjene sjemenkama kima u odnosu na kontrolnu skupinu. Ukupni kolesterol, trigliceridi, LDL-kolesterol i glutaminska oksalooctena transaminaza (GOT) znakovito su sniženi u skupinama u kojima su pšenične mekinje zamijenjene sjemenkama kima, dok je HDL-kolesterol znakovito povišen. Nadalje, koncentracija malondialdehida (MDA) u jetri znakovito je snižena, dok su vitamin E, linolna i alfa-linolna kiselina znakovito porasli $(\mathrm{P}<0,05)$ uslijed dodanih sjemenki kima. Može se zaključiti da zamjena obroka s pšeničnim mekinjama obrokom sa sjemenkama kima može poboljšati nesenje i kvalitetu jaja te smanjiti lipidnu peroksidaciju u kokoši nesilica.

Ključne riječi: obrok sa sjemenkama kima; pšenične mekinje; nesilice; kvaliteta jaja; lipidna peroksidacija; masne kiseline 